\title{
ISLAM MODERAT KONTEKS INDONESIA DALAM PERSPEKTIF HISTORIS
}

\author{
Oleh: Miftahuddin*
}

\begin{abstract}
Abstrak
Sungguh sangat menyedihkan apabila perbedaan dalam Islam, yang pada dasarnya berangkat dari perbedaan pemahaman dan penafsiran atas teks al-Qur'an dan al-Hadits, mengakibatkan ketidakharmonisan dalam bermasyarakat dan bernegara. Sebenarya, sepanjang perbedaan yang ada dilandasi dengan semangat nilai-nilai ukhuwah basyariah (persaudaraan antar umat manusia), ukhuwah Islamiyah (persaudaraan antar sesama umat Islam), hablu minannaas (hubungan baik dengan sesama manusia), dan ikhtilafu ummati rahmatun (perbedaan adalah rahmat), tidaklah menimbulkan permasalahan. Khususnya di Indonesia, dari fakta yang dapat dilihat, tampaknya belum memperlihatkan bahwa perbedaan itu rahmat. Dengan demikian, artikel ini mengajak untuk mencoba melihat kembali sejarah, bagaimana memahami Islam dan ber-Islam yang seharusnya diterapkan dalam konteks Indonesia sehingga manusia Indonesia dalam berpaham tidak terjebak ke dalam ekstrimitas yang berlebihan.

Konsep "Islam moderat", pada dasarnya hanyalah sebatas tawaran yang semata-mata ingin membantu masyarakat pada umumnya dalam memahami Islam. Bersikap moderat dalam ber-Islam bukanlah suatu hal yang menyimpang dalam ajaran Islam, karena hal ini dapat ditemukan rujukannya, baik dalam al-Qur'an, al-Hadits, maupun perilaku manusia dalam sejarah. Mengembangkan pemahaman "Islam moderat" untuk konteks Indonesia dapatlah dianggap begitu penting. Bukankah diketahui bahwa di wilayah ini terdapat bayak paham dalam Islam, beragam agama, dan multi-etnis. Konsep "Islam moderat mengajak, bagaimana Islam dipahami secara kontekstual, memahami bahwa perbedaan dan keragaman adalah sunnatullah, tidak dapat ditolak keberadaannya. Jika hal ini diamalkan, dapat diyakini Islam akan menjadi agama rahmatan lil alamin.
\end{abstract}

Kata Kunci: ber-Islam konteks Indonesia, dialog, Islam moderat, perbedaan, dan sunntullah.

Dari awal diakui bahwa fenomena keragaman agama dan budaya di kalangan umat manusia dari zaman dahulu kala sampai hari ini adalah fakta yang tidak mungkin diingkari. Mengingkari fakta ini sama saja dengan sikap tidak mengakui adanya cahaya matahari di kala siang bolong. ${ }^{1}$

${ }^{*}$ Dosen Prodi Ilmu Sejarah, Jurusan Pendidikan Sejarah, FISE UNY.

${ }^{1}$ Ahmad Syafi'i Ma'arif, (2009), Islam dalam Bingkai Keindonesiaan dan Kemanusiaan; Sebuah Refleksi Sejarah, Bandung: Mizan, hlm. 166. 


\section{A. Pendahuluan}

Dalam Islam, rujukan beragama memang satu, yaitu al-Qur'an dan alHadits, namun fenomena menunjukkan bahwa wajah Islam adalah banyak. Ada berbagai golongan Islam yang terkadang mempunyai ciri khas sendiri-sendiri dalam praktek dan amaliah keagamaan. Tampaknya perbedaan itu sudah menjadi kewajaran, sunatullah, dan bahkan suatu rahmat. Quraish Shihab mencatat, bahwa

"keanekaragaman dalam kehidupan merupakan keniscayaan yang dikehendaki Alah. Termasuk dalam hal ini perbedaan dan keanekaragaman pendapat dalam bidang ilmiah, bahkan keanekaragaman tanggapan manusia menyangkut kebenaran kitab-kitab suci, penafsiran kandungannya, serta bentuk pengamalannya”. 2

Yang menjadi permasalahan adalah dapatkah dari yang berbeda tersebut dapat saling menghormati, tidak saling menyalahkan, tidak menyatakan paling benar sendiri, dan bersedia berdialog, sehingga tercermin bahwa perbedaan itu benar-benar rahmat. Jika ini yang dijadikan pijakan dalam beramal dan beragama, maka inilah sebenarnya makna konsep "Islam moderat”. Artinya, siapa pun orangnya yang dalam beragama dapat bersikap sebagaimana kriteria tersebut, maka dapat disebut berpaham Islam yang moderat. Walaupun dalam Islam sendiri konsep "Islam moderat” tidak ada rujukannya secara pasti ${ }^{3}$, akan tetapi untuk membangun ber-Islam yang santun dan mau mengerti golongan lain, tanpa mengurangi prinsip-prinsi Islam yang sebenarnya, konsep “Islam moderat” tampaknya patut diaktualisasikan.

Berpaham Islam moderat sebagaimana disebutkan, sebenarnya tidaklah sulit mencari rujukannya dalam sejarah perkembangan Islam, baik di wilayah asal Islam itu sendiri maupun di Indonesia. Lebih tepatnya, Islam moderat dapat merujuk, jika di wilayah tempat turunnya Islam, kepada praktek Islam yang dilakuakan Nabi Muhammad dan para sahabatnya, khususnya al-Khulafa al-Rashidin, sedangkan dalam konteks Indonesia dapat merujuk kepada para penyebar Islam yang terkenal dengan sebutan Walisongo. Generasi pengusung Islam moderat di Indonesia berikutnya, hanya sekedar miniatur, mungkin

${ }^{2}$ M. Quraish Shihab, (2007), Secercah Cahaya Ilahi: Hidup Bersama AlQur'an, Bandung: Mizan, hlm.52.

${ }^{3}$ Hanya saja istilah "Islam moderat" mungkin lebih dekat dengan konsep umatan wasatan (menjadi umat yang tengah-tengah), terutama dalam amaliah keagamaan. 
dapat merujuk kepada praktek Islam yang dilakuakan organisasi semacam Muhammadiyah dan NU (Nahdatul Ulama). Ber-Islam dalam konteks Indonesia semacam ini lebih cocok diungkapkan, meminjam konsepnya Syafi'i Ma’arif, dengan ber-“Islam dalam Bingkai Keindonesiaan”. A Azyumardi Azra juga kerap menyebut bahwa Islam moderat merupakan karakter asli dari keberagamaan Muslim di Nusantara. ${ }^{5}$

Sebagaimana dikatakan, ketika sudah memasuki wacana dialog peradaban, toleransi, dan kerukunan, sebenarnya ajaran yang memegang dan mau menerima hal tersebut lebih tepat disebut sebagai moderat. Jadi, ajaran yang berorientasi kepada perdamaian dan kehidupan harmonis dalam keberbagaian, lebih tepat disebut moderat, karena gerakannya menekankan pada sikap menghargai dan menghormati keberadaan “yang lain” (the other). Term moderat adalah sebuah penekanan bahwa Islam sangat membenci kekerasan, karena bedasarkan catatan sejarah, tindak kekerasan akan melahirkan kekerasan baru. Padahal, Islam diturunkan Allah adalah sebagai rahmatan lil alamin (rahmat bagi seluruh masyarakat dunia). ${ }^{6}$

\section{B. Akar Islam Moderat di Indonesia}

Sejak kedatangan Islam di bumi Indonesia, sepanjang menyangkut proses penyebarannya sebagai agama dan kekuatan kultur, sebenarnya ia telah menampakkan keramahannya. Dalam konteks ini, Islam disebarkan dengan cara damai, tidak memaksa pemeluk lain untuk masuk agama Islam, menghargai budaya yang tengah berjalan, dan bahkan mengakomodasikannya ke dalam kebudayaan lokal tanpa kehilangan identitasnya. Ternyata sikap toleran inilah yang banyak menarik simpatik masyarakat Indonesia pada saat itu untuk mengikuti ajaran Islam. Sementara itu, Walisongo adalah arsitek yang handal dalam pembumian Islam di Indonesia.

Menurut catatan Abdurrahman Mas'ud, ${ }^{7}$ Walisongo merupakan agenagen unik Jawa pada abad XV-XVI yang mampu memadukan aspek-aspek spiritual dan sekuler dalam menyiarkan Islam. Posisi mereka dalam kehidupan

${ }^{4}$ Lihat buku Ahmad Syafi'i Ma'arif, (2009), Islam dalam Bingkai Keindonesiaan dan Kemanusiaan; Sebuah Refleksi Sejarah, Bandung: Mizan.

${ }^{5}$ Lihat M. Hilaly Basya, "Menelusuri Artikulasi Islam Moderat di Indonesia”, http://www.madina-sk.com/index.php?option=com, diakses tanggal 23 Juli 2009.

${ }^{6}$ Ibid.

${ }^{7}$ Abdurrahman Mas’ud, (2006), Dari Haramain ke Nusantara: Jejak Intelektual Arsitek Pesantren, Jakarta: Kencana, hlm. 54-58. 
sosiokultural dan religius di Jawa begitu memikat hingga bisa dikatakan Islam tidak pernah menjadi the religion of Java jika sufisme yang dikembangkan oleh Walisongo tidak mengakar dalam masyarakat. Rujukan ciri-ciri ini menunjukkan ajaran Islam yang diperkenalkan Walisongo di Tanah Jawa hadir dengan penuh kedamaian, walaupun terkesan lamban tetapi meyakinkan. Berdasarkan fakta sejarah, bahwa dengan cara menoleransi tradisi lokal serta memodifikasinya ke dalam ajaran Islam dan tetap bersandar pada prinsipprinsip Islam, agama baru ini dipeluk oleh bangsawan-bangsawan serta mayoritas masyarakat Jawa di pesisir utara.

Transmisi Islam yang dipelopori Walisonggo merupakan perjuangan brilian yang diimplementasikan dengan cara sederhana, yaitu menunjukkan jalan dan alternatif baru yang tidak mengusik tradisi dan kebiasaan lokal, serta mudah ditangkap oleh orang awam dikarenakan pendekatan-pendekatannya konkrit dan realistis, tidak njelimet, dan menyatu dengan kehidupan masyarakat. Model ini menunjukkan keunikan sufi Jawa yang mampu menyerap elemen-elemen budaya lokal dan asing, tetapi dalam waktu yang sama masih berdiri tegar di atas prinsip-prinsip Islam. ${ }^{8}$

Demikian pula dikatakan, bahwa proses pergumulan Islam dengan kebudayaan setempat yang paling intensif terlihat pada zaman Walisongo. Masa ini merupakan masa peralihan besar dari Hindu-Jawa yang mulai pudar menuju fajar zaman Islam. Keramahan terhadap tradisi dan budaya setempat itu diramu menjadi watak dasar budaya Islam pesantren. Wajah seperti itulah yang manjadikan Islam begitu mudah diterima oleh berbagai etnis yang ada di Nusantra. Hal ini terjadi karena ada kesesuaian antara agama baru (Islam) dan kepercayaan lama. Setidaknya, kehadiran Islam tidak mengusik kepercayaan lama, tetapi sebaliknya kepercayaan tersebut diapresiasi dan kemudian diintegrasikan ke dalam doktrin dan budaya Islam. ${ }^{9}$

Tampaknya Walisongo sadar, bagaimana seharusnya Islam dibumikan di Indonesia. Mereka paham bahwa Islam harus dikontekskan, tanpa menghilangkan prinsip-prinsip dan esensi ajaran, sesuai dengan kondisi wilayah atau bumi tempat Islam disebarkan. Inilah yang kemudian dikenal dengan konsep “pribumisasi Islam”. Gagasan ini dimaksudkan untuk

\section{${ }^{8}$ Ibid, hlm. 67.}

${ }^{9}$ Abdul Mun'im DZ, “Pergumulan Pesantren dengan Kebudayaan”, dalam Badrus Sholeh (ed.), (2007), Budaya Damai Komunitas Pesantren, Jakarta: LP3ES, hlm. 41. 
mencairkan pola dan karakter Islam sebagai suatu yang normatif dan praktek keagamaan menjadi sesuatu yang kontekstual. Dalam "pribumisasi Islam” tergambar bagaimana Islam sebagai ajaran yang normatif berasal dari Tuhan diakomodasikan ke dalam kebudayaan yang berasal dari manusia tanpa kehilangan identitasnya masing-masing. Lebih konkritnya, kontekstual Islam dipahami sebagai ajaran yang terkait dengan konteks zaman dan tempat. Perubahan waktu dan perbedaan wilayah menjadi kunci untuk kerja-kerja penafsiran dan ijtihad. Dengan demikian, Islam akan mampu terus memperbaharui diri dan dinamis dalam merespon perubahan zaman. Selain itu, Islam dengan lentur mampu berdialog dengan kondisi masyarakat yang berbeda-beda dari sudut dunia yang satu ke sudut yang lain. Kemampuan beradaptasi secra kritis inilah yang sesungguhnya akan menjadikan Islam dapat benar-benar shalih li kulli zaman wa makan ${ }^{10}$ (cocok untuk setiap zaman dan tempat).

Pertanyaan yang muncul kemudian adalah apakah praktek Islam sebagaimana yang diajarkan Walisongo dan diamalkan oleh sebagian besar masyarakat Jawa dapat disebut Islam kaffah atau Islam yang benar. Beragam pandangan pun muncul terkait dengan hal ini, baik dari beberapa golongan dalam Islam sendiri maupun para pengamat asing dan dalam negeri. Misalnya, Geertz adalah salah satu tokoh yang menyangsikan ke-Muslim-an mayoritas orang Jawa, karena fenomena sinkretisme begitu nyata di kalangan mereka. ${ }^{11}$ Cliffort Geertz merupakan tokoh penting dalam studi Islam Jawa yang mengatakan praktek keagamaan orang Jawa campur aduk dengan unsur-unsur tradisi-tradisi non Islam. Menurutnya, kelompok priyayi dan abangan dengan jelas mencerminkan tipisnya pengaruh Islam dalam kehidupan orang Jawa. Bahkan, dalam pandangannya, kelompok yang diangap paling Islami, yaitu santri tidak terlepas dari pengaruh tradisi pra-Islam. Identitas ke-Islaman orang Jawa kurang lebih sama dengan "Islam nominal”. ${ }^{12}$

Sebaliknya, pengamat lain menyebutkan, mungkin benar bahwa Islam di Asia Tenggara secara geografis adalah periferal, Islam nominal, atau Islam yang jauh dari bentuk “asli” yang terdapat dan berkembang di pusatnya, yaitu

${ }^{10}$ M. Imdadun Rahmat, “slam Pribumi, Islam Indonesia”, dalam M. Imdadun Rahmat (et al.), (2003), Islam Pribumi: Mendialogkan Agama Membaca Realitas, Jakarta: Erlangga, hlm. xx-xxi.

${ }^{11}$ Ahmad Syafi'i Ma’arif, (2009), op. cit, hlm. 60-61.

${ }^{12}$ Lihat Hendro Prasetyo, "Mengislamkan Orang Jawa: Antropologi Baru Islam Indonesia”, Islamika No.3, Januari-Maret 1994, hlm. 75. 
Timur Tengah. Akan tetapi, Islam di Asia Tenggara periferal dari segi ajaran perlu diuji secara kritis. Jadi, tidak berarti tradisi intelektual yang berkembang di Asia Tenggara sejak masa awalnya terlepas dari “tradisi besar” Islam. Bahkan, khususunya sejak abad ke 17, dapat disaksikan semakin tingginya intensitas dan kontak intelektual keagamaan antara Timur Tengah dengan Nusantara, yang pada esensinya bertujuan mendekatkan "tradisi lokal” Islam di Asia tenggara dengan "tradisi besar" (tradisi normatif dan idealistik) sebagaimana terdapat dalam sumber-sumber pokok ajaran Islam al-Qur'an dan Sunnah. ${ }^{13}$

Demikian pula, berdasarkan kesimpulan Mark Woodward, kalau ditelaah secara mendalam dan ditinjau dari segi perspektif Islam secara luas, didapati bahwa hampir seluruh ajaran, trdisi, dan penekanan yang bersifat spiritual yang selama ini berkembang dalam masyarakat Jawa, pada dasarnya bersumber dari ajaran Islam di Timur Tengah. Apa yang dikenal dalam upacara keagamaan Jawa, seperti grebeg, selametan, kalimasodo, adalah bagian dari ajaran Islam. Selain itu, doktrin Kawula Gusti Martabat Tujuh dan tradisi wayang yang dikenal dan dilestarikan dalam masyarakat Jawa, dapat ditelusuri asal usulnya dari tradisi tasawuf Islam. ${ }^{14}$

Sejalan dengan pernyataan Woodward dan Azra, dapatlah dibenarkan bahwa tidak satu pun budaya di dunia ini yang tidak sikretik, karena semua budaya pasti memiliki aspek historisnya yang tidak tunggal dan dengan demikian bersifat sinkretik. ${ }^{15}$ Baik agama maupun budaya tidak dapat mengelak dari proses yang tak mungkin terhindarkan, yakni perubahan. Memang benar, ajaran agama sebagaimana tercantum secara tekstual dalam kitab suci, kata demi kata tetap seperti keadaannya semula. Akan tetapi, begitu ajaran agama harus dipahami, ditafsirkan, dan diterjemahkan ke dalam perbuatan nyata dalam suatu setting budaya, politik, dan ekonomi tertentu, maka pada saat itu pemahaman yang didasari ajaran agama tersebut pada dasarnya telah berubah menjadi kebudayan. ${ }^{16}$

\footnotetext{
${ }^{13}$ Azyumardi Azra, (2000), Renaisans Islam Asia Tenggara: Sejarah Wacana dan Kekuasaan, Bandung: Rosdakarya, hlm. 8.

${ }^{14}$ Alwi Shihab, (1997), Islam Inklusif: Menuju Sikap Terbuka dalam Beragama, Bandung: Mizan, hlm. 314.

${ }^{15} \mathrm{Ibid}$, hlm. 79.

${ }^{16}$ Bambang Pranowo, (1999), Islam Faktual: Antara Tradisi dan Relasi Kuasa, Yogyakarta: Adicita, hlm. 20.
} 
Menurut Fazlur Rahman, memang secara historis sumber utama Islam adalah wahyu ilahi yang kemudian termuat dalam kitab yang di sebut alQur'an. Namun, kitab ini tidak turun sekaligus dalam jangka waktu berbarengan, melainkan turun sedikit demi sedikit dan baru terkumpul setelah beberapa puluh tahun lamanya. Oleh karena itu, wahyu jenis ini merupakan reaksi dari kondisi sosial historis yang berlangsung pada saat itu. Hubungan antara pemeluk dan teks wahyu dimungkinkan oleh aspek normatif wahyu itu, adapun pola yang berlangsung berjalan melalui cara interpretasi. Teks tidak pernah berbicara sendiri, dan ia akan bermakna jika dihubungkan dengan manusia. Apa yang diperbuat, disetujui, dan dikatakan oleh Rasul adalah hasil usaha (ijtihad) Rasul memahami dimensi normatif wahyu. Sementara itu, upaya interpretasi Rasul terhadap teks dipengaruhi oleh situasi historis yang bersifat partikular pada masanya. Bahkan, tidak jarang Rasul sendiri sering mengubah interpretasinya terhadap al-Qur'an jika diperlukan. ${ }^{17}$

Terjadinya pluralitas budaya dari penganut agama yang sama tidak mungkin dihindari ketika agama tersebut telah menyebar ke wilayah begitu luas dengan latar belakang kultur yang beraneka ragam. Dalam interaksi dan dialog antara ajaran agama dengan budaya lokal yang lebih bersifat lokal itu, kuat atau lemahnya akar budaya yang telah ada sebelumnya dengan sendirinya akan sangat menentukan terhadap seberapa dalam dan kuat ajaran agama yang universal mencapai realitas sosial budaya lokal. Pluralitas wajah agama itu dapat pula diakibatkan respons yang berbeda dari penganut agama yang sama terhadap kondisi sosial, budaya, maupun ekonomi yang mereka hadapi. Dari perspektif inilah dapat diterangkan mengapa, misalnya, gerakan Islam yang selama ini dikenal sebagai “modernis" yakni Muhammadiyah cenderung memperoleh dukungan yang kuat di daerah perkotaan, sedangkan NU yang sering disebut sebagai golongan "tradisional” memperoleh pengaruh luas di daerah pedesaan. ${ }^{18}$

Jadi, yang perlu digarisbawahi adalah meskipun suatu agama itu diajarkan oleh Nabi yang satu dan kitab suci yang satu pula, tetapi semakin agama tersebut berkembang dan semakin besar jumlah penganut serta semakin luas daerah pengaruhnya, maka akan semakin sukar pula kesatuan wajah dari agama tersebut dapat dipertahankan. Karena, sewaktu ajaran dan agama yang berasal dari langit itu hendak dilendingkan ke dataran empirik, maka mau tidak

\footnotetext{
${ }^{17}$ Lihat Hendro Prasetyo, op. cit, hlm. 80.

${ }^{18}$ Bambang Pranowo, (1999), op. cit, hlm. 19.
} 
mau harus dihadapkan dengan serangkaian realitas sosial budaya yang sering kali tidak sesuai atau bahkan bertentangan dengan ajaran agama yang hendak dikembangkan. ${ }^{19}$

“Tidak ada satu pun agama yang tidak berangkat dari sebuah respon sosial. Semua bertolak dan bergumul dari, untuk, dan dengannya. Ketika agama yang merupkan titah suci Tuhan berdialektika dengan relitas sosial, berarti ia masuk pada kubangan sejarah, atau menyejarah. Sejarah, ruang, dan waktu adalah penguji kebenaran serta kekokohan eksistensi agama. Sebagai penguji, sejarah tentu memiliki seperangkat bahan ujian. Bahan itu adalah unsur-unsur budaya setempat, fenomena dan budaya baru, serta rasionalitas.”20

Sekali lagi, perselingkuhan antara agama dan tradisi adalah sunatullah. Tradisi adalah pemikiran manusia yang profan atas teks-teks keagamaan yang sakral. Dengan demikian, relasi Islam dan tradisi dalam pemikiran umat Islam sangatlah erat. Memahami Islam tanpa sokongan penguasaan warisan intelektual para pendahulu amat sulit mencapai titik kesempurnaan. Namun, tradisi bukanlah segalanya, ia tetap dalam ketidak sempurnaannya sebagai buah pemikiran yang amat serat nilai. Ia harus disikapi secara proporsional dan tidak boleh dikurangi atau dilebih-lebihkan dari kepastian sebenarnya. ${ }^{21}$

\section{Miniatur Islam Moderat}

Fakta moderasi Islam itu dibentuk oleh pergulatan sejarah Islam Indonesia yang cukup panjang. Muhammadiyah dan NU adalah dua organisasi Islam yang sudah malang-melintang dalam memperjuangkan bentuk-bentuk moderasi Islam, baik lewat institusi pendidikan yang mereka kelola maupun kiprah sosial-politik-keagamaan yang dimainkan. Oleh karena itu, kedua organisasi ini patut disebut sebagai dua institusi civil society yang amat penting bagi proses moderasi negeri ini. Muhammadiyah dan NU merupakan dua organisasi sosial-keagamaan yang berperan aktif dalam merawat dan menguatkan jaringan dan institusi-insitusi penyangga moderasi Islam, bahkan

\footnotetext{
${ }^{19}$ Ibid, hlm. 18.

${ }^{20}$ Said Agiel Siradj, “Tradisi dan Reformasi Keagamaan”, Republika, 2 Juni 2007.

${ }^{21}$ Ibid.
} 
menjadikan Indonesia sebagai proyek percontohan toleransi bagi dunia luar. ${ }^{22}$ Dikatakan pula, sebagai organisasi Islam terbesar di Indonesia, NU selama ini memainkan peran yang signifikan dalam mengusung ide-ide keislaman yang toleran dan damai. ${ }^{23}$

Muhammadiyah, misalnya, adalah suatu pergerakan sosial-keagamaan modern yang bertujuan untuk mengadaptasikan ajaran-ajaran Islam yang murni ke dalam kehidupan dunia modern Indonesia. Dalam usaha mencapai tujuan tersebut, gerakan ini secara luas telah mendapatkan inspirasi dari ide-ide pembaruan Syaikh Muhammad Abduh, yang mengobarkan semangat pembaruan pemahaman dan pembersihan Islam dari daki-daki sejarah yang selama ini dianggap bagian tak terpisahkan dari Islam. ${ }^{24}$

Dalam sejarah kolonialisme di Indonesia, Muhammadiyah dapat disebut moderat, karena lebih menggunakan pendekatan pendidikan dan transformasi budaya. Karakter gerakan Muhammadiyah terlihat sangat moderat, terlebih jika dibandingkan dengan gerakan Islam yang menggunakan kekerasan dalam perjuangan mengusir penjajah, sebagaimana ditunjukkan oleh gerakan-gerakan kelompok tarekat yang melakukan pemberontakan dengan kekerasan. Dalam perjalanan sejarah selanjutnya, NU dan Muhammadiyah adalah organisasi Islam yang paling produktif membangun dialog di kalangan internal masyarakat Islam, dengan tujuan membendung gelombang radikalisme. Dengan demikian, agenda Islam moderat tidak bisa dilepas dari upaya membangun kesaling-pahaman (mutual understanding) antar peradaban. $^{25}$

Sikap moderasi Muhammadiyah sebenarnya sejak awal telah dibangun oleh pendiri organisasi ini, yaitu K.H. Ahmad Dahlan. Dikatakan, bahwa salah satu pelajaran yang paling penting dari kepemimpinan Ahmad Dahlan adalah komitmen kuatnya kepada sikap moderat dan toleransi beragama. Selama kepemimpinannya dapat terlihat adanya kerja sama kreatif dan harmonis dengan hampir semua kelompok masyarakat. Bahkan, dengan rekan

\footnotetext{
${ }^{22}$ Novriantoni Kahar, ”Islam Indonesia Kini: Moderat Keluar, Ekstrem di Dalam?”, http://islamlib.com/id/artikel/islam-indonesia-kini-moderat-keluar-ekstremdi-dalam/, diakses tanggal 23 Juli 2009.

${ }^{23}$ Ahmad Zainul Hamid. "NU dalam Persinggungan Ideologi: Menimbang Ulng Moderasi Keislaman Nahdatul Ulama”. Afkar, Edisi No. 21 Tahun 2007. hlm. 28.

${ }^{24}$ Alwi Shihab, (1997), op. cit, hlm. 303-304.

${ }^{25}$ M. Hilaly Basya, op. cit.
} 
Kristennya, beliau mampu mengilhami rasa hormat dan kekaguman. Contoh yang paling menarik dari kemampuan K.H. Ahmad Dahlan adalah mengikat persahabatan erat dengan banyak pemuka agama Kristen. Kenyataan, bahwa beliau dikenal sebagai orang yang toleran terhadap kaum misionaris Kristen, akan tetapi tidak berarti lantas beliau mengkompromikan prinsip-prinsipnya. Dia adalah seorang praktisi dialog antar-agama yang sejati, dalam pengertian dia mendengar apa yang dikatakan dan memperhatikan apa yang tersirat di balik kata yang diucapkan. ${ }^{26}$ Dalam perkembangan lebih lanjut, Syafi'i mencatat, bahwa

"gerakan modernis itu, terutama Muhammadiyah semakin mempertimbangkan dimensi kultural dalam gerak dakwahnya sehingga terasa menjadi lebih lentur tanpa kehilangan prinsip dan misi utamanya. Persis dan Al-Irsyad tetap bertahan, tetapi tidak pernah mengikuti mitranya Muhammadiyah yang terus berekspansi”. ${ }^{27}$

Sementara itu, sikap moderasi NU pada dasarnya tidak terlepas dari akidah Ahlusunnah waljama'ah (Aswaja) yang dapat digolongkan paham moderat. Dalam Anggaran Dasar NU dikatakan, bahwa NU sebagai Jam'iyah Diniyah Islamiyah berakidah Islam menurut paham Ahlussunah waljamaah dengan mengakui mazhab empat, yaitu Hanafi, Maliki, Syafi'i, dan Hambali. Penjabaran secara terperinci, bahwa dalam bidang akidah, NU mengikuti paham Ahlussunah waljamaah yang dipelopori oleh Imam Abu Hasan AlAsy'ari, dan Imam Abu Mansyur Al-Maturidi. Dalam bidang fiqih, NU mengikuti jalan pendekatan (al-mazhab) dari Mazhab Abu Hanifah Al-Nu'man, Imam Malik ibn Anas, Imam Muhammad ibn Idris Al-Syafi'i, dan Ahmad ibn Hanbali. Dalam bidang tasawuf mengikuti antara lain Imam al-Junaid alBagdadi dan Imam al-Ghazali, serta imam-imam yang lain. ${ }^{28}$

Perkataan Ahlusunnah waljama'ah dapat diartikan sebagai "para pengikut tradisi Nabi Muhammad dan ijma (kesepakatan) ulama". ${ }^{29}$ Sementara itu, watak moderat (tawassuth) merupakan ciri Ahlussunah waljamaah yang paling menonjol, di samping juga i'tidal (bersikap adil), tawazun (bersikap

${ }^{26}$ Alwi Shihab, (1997), op. cit, hlm. 311-312.

${ }^{27}$ Ahmad Syafii Maarif, (2009), op. cit, hlm. 62.

${ }^{28}$ Mujamil Qomar, (2002), NU Liberal; Dari Tradisionalisme Ahlusunnah ke Universalisme Islam, Bandung: Mizan, hlm. 62.

${ }^{29}$ Zamakhsyari Dhofier, (1994), Tradi Pesantren; Studi Tentang Pandangan Hidup Kiai, Jakarta: LP3ES, hlm.148. 
seimbang), dan tasamuh (bersikap toleran), sehingga ia menolak segala bentuk tindakan dan pemikiran yag ekstrim (tatharruf) yang dapat melahirkan penyimpangan dan penyelewengan dari ajaran Islam. Dalam pemikiran keagamaan, juga dikembangkan keseimbangan (jalan tengah) antara penggunaan wahyu (naqliyah) dan rasio ('aqliyah) sehingga dimungkinkan dapat terjadi akomodatif terhadap perubahan-perubahan di masyarakat sepanjang tidak melawan doktrin-doktrin yang dogmatis. Masih sebagai konsekuensinya terhadap sikap moderat, Ahlussunah waljamaah juga memiliki sikap-sikap yang lebih toleran terhadap tradisi di banding dengan paham kelompok-kelompok Islam lainnya. Bagi Ahlussunah, mempertahankan tradisi memiliki makna penting dalam kehidupan keagamaan. Suatu tradisi tidak langsung dihapus seluruhnya, juga tidak diterima seluruhnya, tetapi berusaha secara bertahap di-Islamisasi (diisi dengan nilai-nilai Islam). ${ }^{30}$

Pemikiran Aswaja sangat toleransi terhadap pluralisme pemikiran. Berbagai pikiran yang tumbuh dalam masyarakat muslim mendapatkan pengakuan yang apresiatif. Dalam hal ini Aswaja sangat responsif terhadap hasil pemikiran berbagai madzhab, bukan saja yang masih eksis di tengahtengah masyarakat (Madzhab Hani, Malik, Syafi'i, dan Hanbali), melainkan juga terhadap madzhab-madzhab yang pernah lahir, seperti imam Daud alDhahiri, Imam Abdurrahman al-Auza'i, Imam Sufyan al-Tsauri, dan lainlain. $^{31}$

Model keberagamaan NU, sebagaimana disebutkan, mungkit tepat apabila dikatakan sebagai pewaris para wali di Indonesia. Diketahui, bahwa usaha para wali untuk menggunakan berbagai unsur non-Islam merupakan suatu pendekatan yang bijak. Bukankah al-Qur'an menganjurkan sebuah metode yang bijaksana, yaitu "serulah manusia pada jalan Tuhanmu dengan hikmah dan nasehat yag baik" (QS. An-Nahl: 125). ${ }^{32}$ Dalam mendinamiskan perkembangan masyarakat, kalangan NU selalu menghargai budaya dan tradisi lokal. Metode mereka sesuai dengan ajaran Islam yang lebih toleran pada budaya lokal. Hal yang sama merupakan cara-cara persuasif yang dikembangkan Walisongo dalam meng-Islam-kan pulau Jawa dan

${ }^{30}$ Ibid, hlm. 65.

${ }^{31}$ Husein Muhammad, "Memahami Sejarah Ahlus Sunnah Waljamaah: Yang Toleran dan Anti Ekstrem”, dalam Imam Baehaqi (ed.), (1999), Kontroversi Aswaja, Yogyakarta: LKiS, hlm. 40.

${ }^{32}$ Abdurrahman Mas’ud, (2004), Intelektual Pesantren: Perhelatan Agama dan Tradisi. Yogyakarta: LKiS, hlm. 9. 
menggantikan kekuatan Hindu-Budha pada abad XVI dan XVII. Apa yang terjadi bukanlah sebuah intervensi, tetapi lebih merupakan sebuah akulturasi hidup berdampingan secara damai. Ini merupakan sebuah ekspresi dari "Islam kultural” atau "Islam moderat” yang di dalamnya ulama berperan sebagai agen perubahan sosial yang dipahami secara luas telah memelihara dan menghargai tradisi lokal dengan cara mensubordinasi budaya tersebut ke dalam nilai-nilai Islam. $^{33}$

\section{Kesimpulan}

Hablu mina Allah dan hablu minannas mungkin dasar yang harus dipegangi dalam beragama, khususnya Islam. Selain menjalin hubungan dengan sang pencipta, Allah, dengan sesempurna mungkin terutama lewat ibadah mahdah, manusia juga dituntut menjalin hubungan secara baik dengan sesamanya. Dengan demikian, apapun orang itu golongannya dalam Islam (jika di Indonesia dikenal ada NU, Muhammadiyah, Persis, al-Irsyad, Hizbut Tahrir (HTI), Ikhwanul Muslimin, Jamaah Tabligh, Lembaga Dakwah Islam Indonesia (LDII), Gerakan Wahabi, dan lainnya) dan apapun keyakinan agamanya haruslah dihormati dan berusaha sepenuhnya untuk menjalin interaksi yang baik dengan mereka.

Jika hal tersebut yang ingin dibangun, sebenarnya dalam Islam mudah mencari rujukannya. Konsep-konsep seperti wasawirhum fil amri (bermusyawarahlah dalam menyelesaikan suatu perkara), laa iqroha fiddin (tidak ada paksaan dalam beragama), ikhtilafu umati rahmatun (perbedaan pendapat adalah rahmat), umatan wasatan (jadilah umat yang moderat), dan lainnya adalah dapat dijadikan pegangan dalam beragama. Tentu saja beberapa konsep tersebut erat kaitannya dengan sikap moderat, mau berdialog, menghormati golongan lain, tidak menyatakan bahwa dirinya atau golongannyalah yang paling benar dalam berpaham, sehingga tidak terjebak pada ekstimitas yang berlebihan. Selanjutnya, sikap beragama semacam ini jika dalam sejarah umat manusia dapat merujuk, misalnya, kepada perilaku Nabi Muhammad, para sahabat Nabi, Walisongo. Sedangkan, dalam perilaku beragama golongan dalam Islam, misalnya, dapat merujuk NU dan Muhammadiyah.

\footnotetext{
${ }^{33}$ Ibid, hlm. 10.
} 


\section{DAFTAR PUSTAKA}

Abdurrahman Mas’ud, (2006), Dari Haramain ke Nusantara: Jejak Intelektual Arsitek Pesantren, Jakarta: Kencana.

-----------------------, (2004), Intelektual Pesantren: Perhelatan Agama dan Tradisi, Yogyakarta: LKiS

Abdul Mun'im DZ, “Pergumulan Pesantren dengan Kebudayaan”, dalam Badrus Sholeh (ed.), (2007), Budaya Damai Komunitas Pesantren, Jakarta: LP3ES.

Ahmad Syafi'i Ma'arif, (2009), Islam dalam Bingkai Keindonesiaan dan Kemanusiaan; Sebuah Refleksi Sejarah, Bandung: Mizan.

Ahmad Zainul Hamid. "NU dalam Persinggungan Ideologi: Menimbang Ulng Moderasi Keislaman Nahdatul Ulama”. Afkar, Edisi No. 21 Tahun 2007.

Alwi Shihab, (1997), Islam Inklusif: Menuju Sikap Terbuka dalam Beragama, Bandung: Mizan.

Azyumardi Azra, (2000), Renaisans Islam Asia Tenggara: Sejarah Wacana dan Kekuasaan, Bandung: Rosdakarya.

Bambang Pranowo, (1999), Islam Faktual: Antara Tradisi dan Relasi Kuasa, Yogyakarta: Adicita.

Hendro Prasetyo, "Mengislamkan Orang Jawa: Antropologi Baru Islam Indonesia”, Islamika, No.3, Januari-Maret 1994.

Hilaly Basya, M., "Menelusuri Artikulasi Islam Moderat di Indonesia”, http://www.madina-sk.com/index.php?option=com, diakses tanggal 23 Juli 2009.

Husein Muhammad, "Memahami Sejarah Ahlus Sunnah Waljamaah: Yang Toleran dan Anti Ekstrem”, dalam Imam Baehaqi (ed.), (1999), Kontroversi Aswaja, Yogyakarta: LKiS.

Imdadun Rahmat, M., ”Islam Pribumi, Islam Indonesia”, dalam M. Imdadun Rahmat (et al.), (2003), Islam Pribumi: Mendialogkan Agama Membaca Realitas, Jakarta: Erlangga. 
Mujamil Qomar, (2002), NU Liberal; Dari Tradisionalisme Ahlusunnah ke Universalisme Islam, Bandung: Mizan.

Novriantoni Kahar, "Islam Indonesia Kini: Moderat Keluar, Ekstrem di Dalam?”, http://islamlib.com/id/artikel/islam-indonesia-kini-moderatkeluar-ekstrem-di-dalam/, diakses tanggal 23 Juli 2009.

Quraish Shihab, M., (2007), Secercah Cahaya Ilahi: Hidup Bersama AlQur'an, Bandung: Mizan.

Said Agiel Siradj, “Tradisi dan Reformasi Keagamaan”, Republika, 2 Juni 2007.

Zamakhsyari Dhofier, (1994), Tradi Pesantren; Studi Tentang Pandangan Hidup Kiai, Jakarta: LP3ES. 